\title{
PIGEON THE OUTLAW: HISTORY AS TEXTS
}

\author{
Stephen Muecke, Alan Rumsey and Banjo Wirrunmarra
}

\section{INTRODUCTION ${ }^{1}$}

The substantive point of this article is to put into print some versions of the story of Jandamarra, ${ }^{2}$ also called Pigeon, a famous Aboriginal 'outlaw' of the Kimberley district of Western Australia (see Map), who in the 1890s worked as a police tracker, then turned against the police, releasing all their prisoners and fleeing to the Kimberley ranges. He and his followers evaded search patrols for over two years, during which time he led several raids upon Kimberley cattle stations, capturing rifles and ammunition which he is said to have planned to use in an all-out campaign to oust European settlers from the area. He was finally shot down in 1897.

The story of Pigeon occupies a significantly central place in representations of the history of Aboriginal-European contact in the Kimberleys. Among Aboriginal communities in that area the story is a living part of local history, and while most Aboriginal people in the region will at least have heard of the story, the main rights to it are recognised as residing with the Bunuba people, especially with such key figures as Banjo Wirrunmarra. Accordingly, the Fitzroy Valley Bunuba community has recently been incorporated into a production company for the purpose of producing a feature film about Pigeon. European versions of the story include a novel by Ion Idriess (1952) and academic-historical accounts by Howard Pederson $(1980,1984)$. Aboriginal writer Colin Johnson has made significant use of the story in a novel (Johnson 1979).

While it is clear that in and through these rewritings of his story Pigeon's actions become the site of ideological contestation (e.g., his representations as 'tragic hero' or 'revolutionary

Stephen Muecke is a lecturer in humanities at the New South Wales Institute of Technology. In 1984 he published 'Reading the Country' with Krim Benterrak and Paddy Roe.

Alan Rumsey teaches in the Department of Anthropology at the University of Sydney. He is especially interested in discourse patterns and their relationship to other aspects of social structure and process. In 1982 he published a grammar of Ungarinyin and has been studying Bunuba since 1978.

Banjo Wirninmarra comes from Ngalarra country in the northwestern part of Bunuba territory near Winjana Gorge. He has worked as a stockman at Fairfield and other Kimberley cattle stations, and was the founder of Pandanus Park, an Aboriginal market garden/settlement on the Fitzroy River. He is widely known as a senior custodian of Bunuba traditions, including the Pigeon story.

1 This article is a joint effort in that it is the product of at least three distinct sets of dialogues: between Banjo and Stephen, Banjo and Alan, and finally between Stephen and Alan. Banjo is not to be held directly responsible for anything beyond what he says in texts 1 and 2, which were transcribed (and annotated) by Alan and Stephen respectively. As for the rest, Stephen is mainly responsible for the parts concerning the problem of "history', and Alan for the parts concerning ways of transeribing oral texts. For their having prodded us into thinking more clearly about the latter, we gratefully acknowledge Bill McGregor's comments on an earlier draft of this paper.

2 For other versions and details of this story, see Idriess 1952, Pederson 1980, 1984, Johnson 1979, Muecke 1982:149-88 and 1983, Thomas 1984:68-78. 


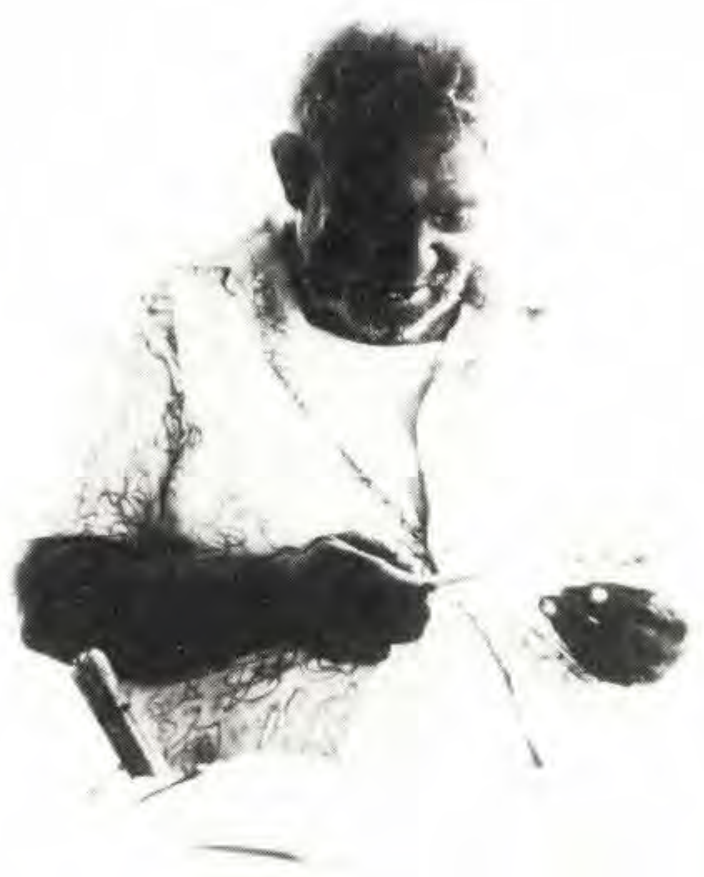

Banjo Wirrunmarra

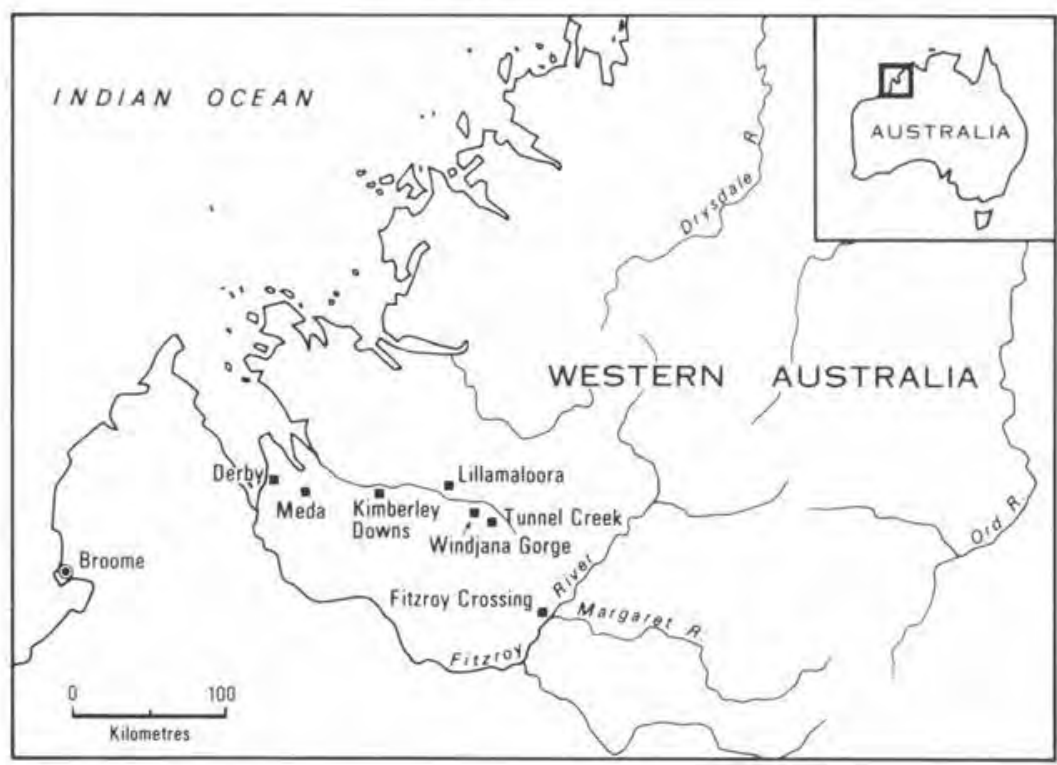

The Kimberley District of Western Australia 
hero'), our aim is not to provide an interpretation of the history of the texts to be reproduced here. Nor is our aim that of laying claim to finally reproducing the authentic and original accounts, even though Banjo Wirrunmarra's name would tend to authorise the texts in this way, central as he is to the sites of Aboriginal (Bunuba) repetitions of the story.

Rather, our methodological aims are to make some general statements concerning 'history as texts' and to outline and justify a particular technique for transcribing oral traditions from tape recordings. These two aims are interrelated in that the method of transcription is one which we believe to be especially suitable for representing some important textual features of Aboriginal oral history in written versions. If we say more about transcription conventions than is necessary for enabling readers to follow the texts, this is because we also want to make the method available to people who might want to use it for transcribing other texts.

\section{HISTORY AS TEXTS.}

History for westerners exists in at least two dimensions. In one dimension it is a sequence of objects that precede the present - a positivism in which the universal ordering function of terms like 'precede' and 'present' is generally assumed without theoretical justification. In the other dimension, history is, as Morphy and Morphy (1984) have put it, "the incorporation or conceptualisation of the past in the present and as such is part of human consciousness and provides a framework for future action' (loc. cit: 459; cf. Bloch 1977). This latter view allows, with the notion of 'incorporation', for an understanding of history as a process of constant reconstruction of its texts according to changing professional protocols. In this sense, there would be a third dimension for the existence of history, and that would be history defined as the activities of history departments, including their principles, professional codes, and politics ('framework for future action').

As linguists, we propose to adopt the second of these points of view in conjunction with what has been called the 'text of history', for two main reasons (cf. Barthes 1982). The first is that we feel that in one important sense the construction of history - whether spoken or written - is a textual activity. What historians do is construct accounts: they form the raw material of events into textual shapes - forms which do not stand in any privileged or transparent relation to the events in question. The second reason concerns the relocation of the spoken word and the development of 'oral history' in Australia and elsewhere.

Until recently, Aboriginal people have generally not been represented as speaking subjects in the literature of Aboriginal history, anthropology, or even biography. ${ }^{3}$ This situation has changed considerably during the last decade. Aboriginal History has flourished as an academic field, partly due to changes in the political position of Aboriginal people, and partly because 'oral history' has now become respectable among the world community of academic historians. Since the founding of this journal in 1977, articles have regularly been published in which Aboriginal people, as authors, co-authors, or collaborators, speak in the first person about history as they have experienced it, both as actors in the narrated events and as interlocutors in earlier oral text productions.

3 For example, even Stanner 1960 - which was one of the first published works in this genre, and is still one of the most sensitive - includes only a handful of quoted utterances by the man whose life story is being told. 
Strictly speaking, no such publication is itself an instance of oral history, since the medium is print rather than talk. To the extent that we are willing to call such productions oral history, this is presumably because they start from spoken accounts as their 'primary sources'. ${ }^{4}$ These spoken accounts are generally recorded on tape, transcribed, and - if in some distinctively Aboriginal form of English - subjected to various lexico-grammatical transformations and other editing procedures before being reproduced in print. For instance, Bruce Shaw says of his collaboration with Jack Sullivan that 'Editing, transforming the narratives from the spoken to the written word, was relatively extensive', so as to place them into 'standard colloquial English' (Shaw and Sullivan 1979:97, cf. Shaw 1984).

It is obvious that a similar editing procedure has been followed in, e.g., Bell (1978), Shaw and McDonald (1978), Shaw and Sullivan (1983), Morphy and Morphy (1984).

Generally, it is only when reproducing 'traditional' Aboriginal-language accounts that authors present verbatim (phonemic) transcripts of what was said. These are usually accompanied by inter-linear glosses, and often by 'free translations' too - the latter in standard or colloquial English (see, e.g., Merlan 1978, Heath 1980).

The effect of these transformations is that, although Aboriginal people are represented in the edited English 'translations' as speaking in the first person, they are made to do so in a voice which is not their own, and much of the meaning of the original oral performance is lost or altered. 5 We believe this situation may be improved upon by using a system of transcription something like the one which has been developed by Dennis Tedlock and his Amerindianist colleagues over the past fifteen years, as expounded in Tedlock (1983). A similar system was developed independently ${ }^{6}$ by Stephen Muecke for the representation of Australian Aboriginal English narratives (Muecke 1982; cf Roe and Muecke 1983, Benterrak et al 1984). The scheme which we propose here draws upon both systems, incorporating what we see as the most useful features of each for publishing Aboriginal oral accounts.

\section{A METHOD OF TRANSCRIPTION.}

In common with Tedlock, our aim is to render the oral text it such a way that it can easily be re-presented or performed in something like its original oral-dramatic form. The conventions which we (and Tedlock) propose for this are - in the main - ones which have

This phrase has been put in quotation marks here because the canons of standard historiographic practice would seem to require written or otherwise 'objectified' speech as 'sources', which are 'primary' because they are understood to provide a kind of 'hard evidence' against which the 'secondary' productions of any particular historian may be 'tested' in order to assess their validity. It is of course possible to treat particular transcripts (or electronic recordings) of particular oral performances in this way, but that sort of objectification has no basis in Aboriginal tradition.

5 This is not to gainsay the considerable strengths of the works cited in the previous two paragraphs. Shaw and Sullivan (1983) in particular goes a long way toward the enfranchisement of Jack Sullivan as a speaking subject, Keesing (1983) notwithstanding. We accept the arguments of Shaw (1984) against Keesing's plea for a more literary 'translation' of Aboriginal English, but favour an approach which is even less compromising than his in its faithfulness to the oral texts. Cf. the remarks by an Aboriginal working party for the Bicentennial History Project: 'When the cues, the repetitions, the language, the distinctively Aboriginal evocations of our experience are removed from the recitals of our people, the truth is lost to us' ('A Black View of History, Culture'. The Age 13/2/81.) 
long been in use for the printing of poetry and plays - western genres with which Aboriginal oral narrative has far more in common than it does with written prose.

The most basic collocational unit which is evident from the sound of those narratives (as opposed to their grammar) is not the clause or the sentence, but what Tedlock calls the line: ${ }^{7}$ a stretch of speech which is bounded on both ends by silence. ${ }^{8}$ Tedlock represents every such 'line' in one line of print beginning at the left margin of the page. Where the spoken line is too long to fit into one line of print, it is continued in an indented one(s). Here we will adopt Tedlock's procedure, with one difference, as per Muecke (1982:187-8). In our scheme, not every pause will be considered to terminate a line. This is because some pauses (a fairly small minority of them) in our tape recordings can clearly be distinguished as hesitations. These sound very different from deliberate pauses because after the pause, the voice begins at the same pitch at which it left off, and continues the pre-pause contour rather than starting a new one. In our scheme, unlike Tedlock's, these hesitation pauses will be considered to fall within the line. All other pauses will be taken as boundary markers between lines. ${ }^{9}$ Pauses within the line will be represented by hyphens.

As in Tedlock's scheme, we indicate prosodic prominence by capitalisation, e.g.: '. . and he told him to GET OUT of it.' (When the word ' $\mathrm{I}$ ' is prominent, this will be shown by boldface.) Another prosodic feature which figures in the Aboriginal texts (and in oral performance generally) is the 'stylistic' use of over-lengthening. We indicate this by repeating letters in proportion to audible length, e.g., if the ' $O$ ' in 'long' is held to three times its normal length, we would write it 'looong'.

Other paralinguistic or prosodic information (including specification of extra long pauses) is occasionally ${ }^{10}$ provided in parentheses, as per standard practice for indicating "stage

7 This is roughly the same unit which is referred to in Muecke 1982 as a 'narrative clause'. Because the latter term could easily be confused with 'clause' as a grammatical unit, we will abandon it in favour of Tedlock's term 'line'. But see below for a (minor) difference in what qualifies for us as a line.

8 These silences are usually at least half a second long, and must be distinguished from the much briefer ones which occur, e.g., during the occlusion of some stop consonants. The latter are not heard as pauses, partly because of their brevity and partly because of the intonational factors discussed below.

9 Note that, although every line break falls at a break between intonation contours, not every contour is coterminous with a line, since the contour boundaries are not always accompanied by a pause. Cf. Halliday 1985, who speaks of tone groups as information units 'one following the other in unbroken succession with no pause or discontinuity between them' (p.274). But although this is often true, it is readily apparent from his examples (pp.274-286) that when a pause does occur it is almost always at the beginning or end of a tone group. Thus on formal grounds it seems reasonable to propose that the line as we have defined it is a higher level unit on the same prosodic hierarchy to which Halliday's 'foot' and 'tone group' also belong (though its functional relationship to the tone group is far from clear). Note that only by excluding hesitation breaks at line markers can this proposal be sustained.

10 Obviously the details which are specified in this way are only a small subset of the ones which could have been noted. Since we have at our disposal no rigorous functional theory on which to base such a selection, we must rely solely upon our sense of what is significant, according to our experience as interlocutors in oral text productions of this kind. Regarding the length of pauses between lines, we now consider Muecke 1982 and Tedlock 1983 to have unduly complicated the transcription by specifying this 'etically' throughout (Muecke in whole-second intervals and Tedlock by specially marking all pauses over two seconds long). Since our experience suggests that not every long pause is ipso focto especially significant, we now specify 'long pause' optionally in parentheses. Our deliberations on this matter owe much to the advice of Bill McGregor, whose help we gratefully acknowledge. 
directions', e.g., (in a soft voice), (points west), (closes eyes) etc.

Where there is a change of speaker, the new speaker is identified by initials at the left margin, followed by a colon. The speakers so identified in the texts below are Banjo Wirrunmarra, Alan Rumsey, and Stephen Muecke. Contra the practice of most writers of 'oral history', 11 but in common with Tedlock (1983:285-343), we think it is important to represent something of the fundamentally dialogic ground of oral texts, fully acknowledging in this case that they are the product of interaction between non-Aboriginal, academic investigators and an Aboriginal 'informant' of considerable skill and experience, both in that role and as a 'story man'.

For spelling Wirrunmarra's English, we have kept as close as possible to standard English orthography. Wirrunmarra's English in these texts is not the stabilised Kriol of Sandefur (1979), but a more-or-less idiosyncratic lect which is generally close enough to Australian colloquial English to be intelligible to English speakers who have no familiarity with Kriol. Where this is not the case, the Aboriginal forms in question are glossed in footnotes.

The above conventions provide what we think is a good compromise between richness of prosodic and contextual detail, and simplicity. Much more phonetic and choreographic detail could have been included, but this would have made the transcripts too complex to be performable in real time and/or readily intelligible to non-linguists. The system which we are advocating here is one which we hope will not only make texts such as the following ones readily available to a non-academic audience, but will facilitate the transcription and publication of them by literate speakers of Aboriginal English with little or no special training in linguistics.

An added advantage of presenting just these audible features is that it then becomes possible to translate (non-English) Aboriginal language texts in such a way as to preserve some of their most important aural features in the English renditions. For line breaks, line-level prosodic prominence, stylistic vowel lengthening, and many paralinguistic features of Aboriginal-language texts (unlike their segmental-phonological and word-level supra-segmental features) have functional values which are largely preserved when these features are incorporated directly into the English-language scripts. ${ }^{12}$ Furthermore, the uses of these features in Aboriginal English are almost identical to their uses in 'traditional' Aboriginal languages. This is well exemplified by the first text below. It starts out in the Ungarinyin Language (see Rumsey (1982) re Ungarinyin grammar; Blake (1981) for orthography), for each line of which we have provided an English translation which carries over the prosodic features notated as per the discussion above. After line 40, the tape recorder was switched off. A few minutes later, it was switched on again, and Wirrunmarra picked up the story where he had left off - now in a variety of Aboriginal English. Note the similarity in average line length, in the uses of prosodic prominence, and in what gets put into a single line.

11 Cf., e.g., Shaw and Sullivan 1979:97, who apologise for the fact that 'parts of the narrative are responses to questions', and delete the questions from the published 'narrative'.

12 It is no accident that Tedlock's system of notation is useful in just this way, for the 'translation of style' from American Indian languages into English was just the purpose for which Tedlock developed the system. 


\section{PIGEON THE OUTLAW}

\section{THE TEXTS.}

The following two texts about Pigeon were recorded seven years apart - the first by Alan Rumsey in 1984, the second by Stephen Muecke in 1977.

We have chosen to present both of these texts in order to provide an example of the nature and extent of the continuity of an Aboriginal oral tradition, as held by a particular story-teller. You can see how some details in the narrated events - e.g. the topographic ones discussed in footnote 26 - are reproduced exactly even after seven years, and others, such as the number of funnels on the Koombana, are slightly altered. An advantage of the system of transcription we are using here is that it also gives you some idea of the enduring particularity of Wirrunmarra's craftsmanship as a shaper of oral history. We will here refrain from detailed comparison of his version of the story with other accounts (but cf. Muecke 1983a), since our aim is not to add to or improve upon Pederson's admirable work of compilation (1980, 1984) but rather to let Wirrunmarra (whom Pederson (1984:14, footnote 7 ) describes as 'custodian of the Pigeon story') speak as directly as possible to our readers. Where extra background information may be required in order to follow what he is saying, this will be given in footnotes rather than in a concluding section, in order to let BW have the last word.

\section{TEXT 1: THE STORY OF JANDAMARRA, ALIAS PIGEON, AS TOLD TO ALAN RUMSEY BY BANJO WIRRUNMARRA, AUGUST, 1984.}

As told in Ungarinyin

anggalu policemana

warraj amanga

Jandamarra

biyinggerri

5 brrru gugudu burrinyirri

burrarda bundumangerri, joli

bundumindanirri

Limalwurru-gu

AR: Limalwurru

10 BW: e e

di-yu NGARD amanga

yali ngawurr ongondu

amara

15 amara, aga

and malngarri-nangga

yone nyindi di winjangun

arrungu di larrug uma

umara amara

di umanga

20 arri cleaner-gu buluba

angga, malyan

\author{
English Translation \\ the policeman came \\ he picked him up \\ Jandamarra \\ the two of them went \\ they chased blackfellas \\ they chained up the lot of \\ them and brought them back \\ to Lillamaloora ${ }^{13}$ \\ Lillamaloora \\ yes \\ then he ASKED him \\ 'I want to kill some kangaroo for them' \\ he said \\ and the white man said 'o.k. \\ you know where the rifle is, \\ hanging up there \\ take it', he said \\ so he took it \\ he looked around for rifle \\ cleaner, 'there's none'
}

13 This is the name of an old police station near where the Lennard River breaks through the Napier Range (see map). Its stone ruins can still be seen. Note that in line 48, after Wirrunmarra has switched to English, he uses the anglicised version of the name. 


\section{ABORIGINAL HISTORY 1985 9:1}

amara

winingara werri

wumen

25 ngawurr on mindi-nga

jinda policeman

galumun-nangga-gurde di

NYADAGA WULUN

30

gugudu biji nyindi

waga

ngawurr anjawu budmaranangga

(long pause)

di-yu NGAWURR oni

di andu yu

andumindanina

35 Windjana Gorge

darag andumindani

mindi-yu andiyilani

burrardangarri

right

40 FINISH

(tape off for a few minutes)

When you ready

AR: oh, you ready?

BW: you ready?

AR: um

45 BW: right

what he done when he shot that man

ah, the place

Lillamaloora

he WENT

50 he was on that cave

in Windjana

AR: Jandamarra jirri (Ungarinyin: 'Jandamarra, that one')

BW: Jandamarra

that Pigeon Hole

55 old Grandfather Blythe came with a .. .? calf

weaners

water'm in Windjana Gorge

when he stoop down and getta water

in Gorge

60 and he told him to GET OUT of it

old Bly the take his, take his TIME to get out of the water

they was that many CATTLE there

anyhow he fired a shot and he KNOCK his THUMB off

old fella jump up he said

he put in one

bullet

he shot him right there

that policeman

from before, that one

'OUR WOMEN

you chase after

why

why don't you shoot him?', they

said to him (long pause)

so he SHOT him

then he himself

he took them

to Windjana Gorge

he took them in

and he kept the lot of them

right there 


\section{PIGEON THE OUTLAW}

65 all the cattle rush

to the bank

he take'm to the open

and THEN

that was that - JANDamarra

70 he wasn't a friend of anybody now ${ }^{14}$

he was on his own

he was a outlaw

and AGAIN

he shot, the young policeman

75 my father

he was runnin' over, what?

one mile

in the plain

Plum plain

80 shot him in the fingers

AR: your father?

BW: my r'own 15

and he got into the spring there

Ninety Two Spring he bin get in there

85 BROAD DAYLIGHT

he had 'nother shot

in the YARD

the old fella still run along

the kid got onto the HORSE

90 go down to Fitzroy Crossin'

tell the police THERE

his BOSS got shot

so he went tooo Oscar Range

when he got into Oscar Range

95 he shot the manager

Doug Waley

one MORNIN'

and he went from there

to King Leopold

100 he had many fight with the Aborigine people up there

they couldn't KILL him

'cause he was a OUTLAW

Jandamarra

14 Here and elsewhere, Wirrunmarra uses the word 'now' to mean 'at this point in the narrated event' rather than 'at the time of this speech event'. This is a standard feature of Kriol and Kimberley Aboriginal English.

15 'rown' is the equivalent of standard English 'own' as in 'my own'. It is common in Kimberley and Top End Aboriginal English, and probably has arisen from a re-segmentation in the analogic base provided by the phrases 'her own', 'their own', 'our own', 'your own', etc. 
and he went 'round again

105 go back to Windjana

stay around there and he came back to Tunnel ${ }^{16}$

he bin LIVE around there

and

Pilmer ${ }^{17}$ got on to him AGAIN

110 so HE shot one police boy in town

so Pilmer got upset

he wanted to FIGHT him

but MANY police

and the stock

115 bin chasing up Jandamarra

but that wasn't good enough

but he was lettin' them go

he didn't want to take the life of man

but YET

120 Minko Mick

he sailed all the way from

Roebourne

with Koombana ${ }^{18}$

see Koombana was a four-funnel

125 big ship

he landed in Derby

so they got a mail coaches

mail coach bin take him from Derby to Meda

and he got on that other one again take him to Kimberley Down

130 and he got on that 'nother one took him to Fairfield

and he - got on to horse

ride over to Tunnel

put on his - belt

he walked down there

135 he nearly shot one old fella

two kid was giggling there

and he shot the - ground for 'em

they roll down

and Minko Mick said 'there, right

16 The reference here is to Tunnel Creek (see map), a cave where Pigeon hid out. This is the same place which in Idriess 1952 is called the 'Cave of Bats'.

17 Pilmer was the constable at Fitzroy Crossing.

18 Cf. the Weekend Australian (April 13-14, 1985, p.3): 'High Tech Search for the Cursed Koombana', which reports that the Koombana was built in Glasgow in 1908 and lost at sea somewhere between Port Hedland and Broome in 1912. She is described as having been the 'pride of the Adelaide Steamship Company's passenger fleet' and as having had a 'distinctive tall funnel'. 


\section{PIGEON THE OUTLAW}

140 you can have this belt' he just put one slug in and he follow the river up and he found him in the behind the boab tree he was up into the hill

145 somebody else fire a shot from 'nother end he turn around and Minko Mick straightaway he shot him in the THUMB

150 his THUMB and there was, his LIFE was in the thumb and that's - he beat him there he was a - a wit doctor 19

AR: witch doctor

155 BW: um - Minko Mick

AR: um - he KNEW that

BW: yeah he knew that

AR: about that THUMB

BW: that's it

160 AR: yeah

BW: that's all the story - Rumsey

AR: yeah?

why did that - ah - Pigeon - how did he know how to - put his life in to his THUMB like that?

165 where did he learn all that stuff? $\mathrm{BW}$ : well only you and I say this murlal jirri ${ }^{20}$

AR: um

$\mathrm{BW}$ : ngawi-nangga

170 lala-nangga walma-nangga gugudu inyi AR: he went with every kind of relation

BW: yeah well that's it

('he was incestuous')

('his father's sister')

('his sister')

('his wife's mother')

('he chased after')

19 'wit doctor' is probably a re-etymologised version of the English 'witch doctor' (cf. Rumsey 1983). In the following line, A.R., who had not noticed this usage before, seeks confirmation that B.W. has in fact said 'witch doctor'. But instead of giving it, B.W. apparently understands A.R. to be asking 'Which doctor?' He responds by repeating the man's name, 'Minko Mick', and then goes on to use the term 'wit doctor', in lines 177, 277.

20 Here BW switches the Ungarinyin language - which he knows to be the one AR understands best - in order to explain how Pigeon gained special powers by breaking the Aboriginal 'law'. Cf. lines 101-2: 'they couldn't KILL him / 'cause he was a OUTLAW', which set up an interesting relationship between Jandamarra/Pigeon's positions vis à vis the Aboriginal 'law' and the European one. 
175 AR: and that's

BW: SO the life was come OON and OON and OON

so - that way he was sort of a WIT doctor

but he was a OUTLAW

because he had his life in his thumb

180 AR: ah yeah

BW: and when they finish - SHOT him there

and they cut that THUMB there

they can see that little HEART was there

AR: ah yeah

185 BW: I don't know HOW they PUT it there

AR: yeah

but you reckon that murlal

BW: um

AR: made him,

190 BW: yowe

TOO CLOSE

murlal too close ${ }^{21}$

AR: and - why did all the Aborigines wanna shoot Pigeon too?

BW: well they didn't understand him

195 why he done it because

way back

Pilmer and Billy Richardson ${ }^{22}$ was SHOOTING PEOPLE

THOUSANDS and THOUSANDS of people, they start from

from

200 eastern state right down

to north

right up - to west

AR: yeah

BW: they were killin'm THOOUUSANDS and THOOUUSANDS of BLACKFELLAS

205 AR: yeah?

BW: but he heard that and some of his people bin get killed too

some of OUR people bin get killed

AR: yeah

$\mathrm{BW}$ : so only one man

210 he had a feeling for his own people

AR: yeah?

21 In other words, the women whom Pigeon "chased' were not only of the wrong classificatory kin categories, they were also among his 'close' relatives within those categories, which means they were doubly proscribed for sex or marriage (cf Rumsey 1981:183,190-1).

22 . Richardson is the 'policeman', 'the white man' referred to lines 1-32 above. It seems interesting that he is never referred to by name there, but only after we have shifted from Aboriginal-language narrative to an English-language 'interview' situation. 
BW: that Pilmer

and Richardson

THEY done it

215 but - SO he had to pay back for that

AR: well at first he was WORKING for that Richardson

BW: yeah with Billy Richardson he was WORKIN' for him AFTERWARD

because he bin shooting people first

him and - Pilmer

220 and after all when Pigeon

get a bit OLDER

come back and work with the POLICE

PATROLLING

so

225 he got a chance then

AR: was he just waiting for that chance the whole time or,

BW: (overlap with end of line above above) MMAYBE

AR: what made him change his mind?

BW: but - somehow that thing bin come, we, I don't know

230 AR: yeah

BW: I can't follow up

AR: do you know of any other people working with Pigeon or was he all by himself?

BW: he had his mate, they call him name Captain

235 AR: Captain

oh yeah

BW: blackfella

and he's the fella

he had - he had a thought

240 'oh - police bin kill'm people'

but they always be talk about

'why these black - blackfellas get shot'

AR: yeah

BW: "by one man

245 thousands of people

WHY?'

AR: yeah

BW: everyone lookin' at

their own people droppin' down with one - slug

250 AR: yeah

BW: one man standin' up there loading gun just like- somebody

blind or-dumb sittin' up

AR: yeah

BW: and they all get shot

255 so

I think Pigeon had a feeling 
after that

and he bin keep PICTURING, you know?

and maybe

260 that's how that thing been comin' to him

and so when he got a chance

so HE had to do it

AR: when he was - when Pigeon was hiding out did he have any woman with him or- just Captain? ${ }^{23}$

265 BW: he had himself, noobody else

he - he done his own battle

AR: yeah

BW: he didn't want to bring anybody in

see, he was goin' to try

270 do it as a THEY done it

same thing well he wanted to do the same thing

give it back to them

one man one man

so he's no friend there

275 AR: yeah

BW: but I- where- I don't understand

why this- wit doctor went up there

this is the thing that I don't understand

AR: yeah

$280 \mathrm{BW}$ : and he bin take a life of BLACK man and BLACK man been get shot by

WHITE people WHY couldn't he leave ALONE?

AR: yeah

BW: that was the story that I understand, you know

AR: if he LEFT it alone what do you think would have happened?

285 BW: well he had ta been a

king of Australia

and everything would have been come back - right way

AR: you reckon?

BW: I reckon

290 AR: all right

BW: he 'ant to been big fella

go on

(grins) might be we been talkin' toooo faar?

23 Idriess 1952 portrays Pigeon as having been accompanied by his mother and a young wife 'Cangamvara' (a most unlikely-looking word for Kimberley Aboriginal languages). 
TEXT 2: PIGEON STORY, AS TOLD TO STEPHEN MUECKE BY BANJO WIRRUNMARRA, 1977

1 BW: now

\section{PIGEON}

Pigeon START OFF

him bin

5 I talk to you

with the Pidgin English, pidgin ${ }^{24}$

white man tongue pidgin

he bin start off got

breakin' in HORSES

10 him bin SHEARER

shearin' sheep

with a BLADE

not a machine

'cos those days they had a blade

(SM: yeah)

15 so he bin work on that one

shearin' blade

he bin work Quanbun

Noonkenbah

Liveringa then he went back to Kimberley Down ${ }^{25}$

20 he work there

an' he went back to p'lice camp

then he start p'trol

he went for p'trol

look around some BLACKFELLAS inna bush

25 he tracking (long pause)

what they done?

they killed two white man

in Mount Broome

then p'lice went up to find him

30 so they pick-im-up

Pigeon the outlaw

they take-im in

up on the range

then Pigeon walk up.

35 an' he got a MOB

an' he bring them back

SOME was there

right one

that bin kill the white man

24 The narrator distinguishes Pigeon's name from that of the variety of Aboriginal English.

25 Names of Kimberley stations. 
but he didn't know who he was

take him to Windjana Gorge

tie them there

an' Pigeon

they turn around tell'-im Pigeon 'alright you wanna get a - kangaroo

45 for us?

we can't jus' sittin' down here starve hungry on the chain

you bin bring us

so you mus' FEED us'

so

50 Pigeon turn around and see boss

the boss (...?) 'I wanna get a - kangaroo for these prisoners'

'Alright you know where the rifle'

so he went up and get the rifle

'stead of he go for -KANGAROO he shot his boss

55 in Windjana

Lillamaloora

that was a p'lice station

(softly) anyhow

he went there

60 got the mob

take-im off from chain

an'

he bin

go in the hill

65 everyone followed him up there

but he the one done all the FIGHTING

an' this OTHERS didn't understand him

(softly) they never have-im fight

anyhow

70 he went across to Ninety Two

he shot one white man there

then he went to Oscar

Oscar Range

station

75 he shot one white man there

early mornin'

then he went down to Plum Plain

he see MOB comin-up gotta horse

stockboys and the p'liceman they ALL come

80 look for Pigeon

then he take off

from that big plain

Plum Plain

they chased him 


\section{PIGEON THE OUTLAW}

85 when he got into the HILL country

he look back he knock that hats off the p'liceman

take his hat off

(knocks table) one bullet

he ask that p'liceman he says

90 'You want you life or you wanta dead?'

p'liceman said 'No I wanta life'

'You go back'

so

he just taste "im but if he wanted-im he hadda kill-im then

95 anyhow he let-im go

he went to Brooking Gorge

corner of Brook or Leopold

an' he went tooo

(long pause followed by brief inaudible section)

100 he went to King Leopold

he get a mob of blackfella there big tribe

they start fight there

they take-it-away one woman from there

young girl

105 they couldn't fight-im

they couldn't foller-im

went back to Windjana

he bin fight for SIX YEARS

and ah

110 governor or government went up there and said

he went up he get up he's there Pigeon 'You there?', 'Yes

I'm here'

'Ah'

well we all friend now you'll have to come down'

115 so Pigeon didn't take a risk

so he knock his hat

said 'you better go off'

said 'ah I don't want to (almost inaudible) ...'

knock his hat off this government bloke whatever he was

120 anyhow he went back again

so (laugh)

(. . .?) stay there too long

anyhow they follered-im up - so LAS' he felt himself

125 he was

he was losing hope

they can put a bullet right across here

shootin-im in here

nothing can come out

not even water 
130 not even a drop of blood

(softly) nothin' doin'

no matter how many shot he used to take here nothing doin'

THAT didn't put him back

anyhow

135 one

maban blackfella witdoctor

come from ROEBOURNE

they used to call'im ah Minko Mick

he got onto the boat

140 in

Roebourne

or Onslow

boat call - er name ah

Koombana

145 three funnel

come right up to Derby landed

anyhow blackfella got onto - mail coaches

they take-im to Meda and from Meda to Kimberley Downs and from Kimberley

Downs to Fairfield ${ }^{26}$

150 then he ride across with horse

horseback

went to Tunnel

he SLEEP one night there

he didn't go fast

155 but next mornin'

they stirred'im Pigeon up

so he got up

to start shooting - but this bloke seen his life

soo

160 witdoctor told them boys

'Alright

I know' he said

'I take jus' one bullet in my rifle' he said 'I'll kill'im an' you fellas can go an' pick 'im up

26 Compare lines 135-52 here with lines 120-32 in text 1. It seems that one form for the "correct rendering' of an Aboriginal history of Pigeon is the ennunciation of series of correctly ordered place names for the movements of the main participants of the events, in this case Pigeon and Minko Mick. The two narratives from BW separsted by seven years maintain this correct ordering. Also, when historical accounts are collectively constructed by Aborigines, a (perhaps the) major task is to establish the names of places and the right sequence of movements among them. This textual and rhetorical feature is in marked contrast to 'Western' historical texts, which instead are periodised around linear time intervals, dates. Obviously, neither historical form relates directly to Truth, but they represent the work of authority in the text and the codification of appropriate knowledges. In this connection, note also the appearance of a place name at the end of this story as an important datum about this particular text production and/or its producer. Pandanus Park is a market garden-cum-Aboriginal settlement along the Fitzroy River, of which BW is identified as the founder. This text was recorded there. 


\section{PIGEON THE OUTLAW}

165 cut his HEAD off

so this Pigeon went up ah

Minko Mick

followed the river up

he got into the boab tree

170 he look up

upwards

Pigeon was right on top in the cliff

so he FIRE ONE shot he knock him in his thumb ${ }^{27}$ - so he fell down an' he sing out

'I shoot'im, you can go in and pick'im up whenever you want

175 very fright they said 'NO we can't run up to pick'im up'

'NO - you go in an' see'im'

'he's finished'

'alright'

oh well they didn't argue with'im all them fellas run up there

180 and see

sure enough Pigeon laying there

smashed up

'is thumb

(pause for tape change)

so when Minko Mick - went up there he looked 'is - thumb he found

185 a little

little heart ${ }^{28}$

like a fish

in his thumb here (shows thumb)

that where he shot

190 an' that was the end of the old Pigeon story

SM: Oh good

BW: it's from Banjo

Pandanus Park

27 In other Aboriginal accounts, Pigeon's 'Achilles' heel' is variously hand, foot, or thumb.

28 A common practice for Aboriginal 'doctors' was (or is) to appear to remove small pieces of quartz, etc. from sick people. 'Little heart' may relate to this practice. 


\section{ABORIGINAL HISTORY $19859: 1$}

\section{BIBLIOGRAPHY}

Barthes, Roland. 'Le discours de l'histoire', Poétique, 49, 1982:13-21.

Bell, Diane. 'IFor our families: the Kurundi walk-off and the Ngurratiji venture', Aboriginal History, 2(1), 1978:32-62.

Benterrak, Krim; Stephen Muecke and Paddy Roe. Reading the country. Perth, 1984.

Blake, Barry. Australian Aboriginal languages. Sydney, 1981.

Bloch, Maurice. 'The past and present in the present', Man, 12, 1977:278-92.

Halliday, Michael A.K. An introduction to functional grammar. London, 1985.

Heath, Jeffrey. Nunggubuyu myths and ethnographic texts. Canberra, 1980.

Idriess, Ion. Outlaws of the Leopolds. Sydney, 1952.

Johnson, Colin. Long live Sandawara. Melbourne, 1979.

Keesing, Nancy. 'Language and Dignity', Australian book review, November, 1983:16-18.

Merlan, Francesca. " "Making people quiet" in the pastoral north: reminiscences of Elsey Station', $A b o-$ riginal History, 2(1), 1978:71-106.

Morphy, Howard and Frances Morphy, "The "myths" of Ngalakan history: ideology and images of the past in northern Australia', Man, 19(3), 1984:459-78.

Muecke, Stephen, 'The structure of Australian Aboriginal narratives in English - a study in discourse analysis'. PhD thesis, University of Western Australia, 1982.

'Discourse, history, fiction: language and Aboriginal history', Australian journal of cultural studies, 1(1), 1983:71-9.

Pederson, Howard. 'Pigeon: an Aboriginal rebel: a study of Aboriginal-English conflict in the West Kimberley, north Western Australia during the 1890s'. BA honours thesis, Murdoch University, 1980.

"Pigeon": an Australian Aboriginal rebel', in Reece, B. and T. Stannage ed. EuropeanAboriginal relations in Western Australian history. Perth, 1984:7-15.

Roe, Paddy and Stephen Muecke. Gularabulu: stories from the West Kimberley. Perth, 1983.

Rumsey, Alan. 'Kinship and context among the Ngarinyin', Oceania, 51(3), 1981:181-92.

An Intra-sentence grammar of Ungarinjin, north-western Australia. Canberra, 1982.

'On some syntactico-semantic consequences of homophony in north-west Australian pidgin/ creole English', in Muehthaeusler, Peter ed. Studies in pidgin and creole linguistics, no.3, Pacific Linguistics, A-65, Canberra, 1983.

Sandefur, John R. An Australian creole in the Northern Territory: a description of the Ngukurr-Bamyili dialects (part 1) Darwin, 1979.

Shaw, Bruce. 'How Aboriginal life histories can be written: a response to the review "Language and Dignity", 'Australian Aboriginal studies, 1984:47-52.

Shaw, Bruce and Sandy McDonald. 'They did it themselves: reminiscences of seventy years', Aboriginal History, 2(2), 1978:122-40.

Shaw, Bruce and Jack Sullivan. " "They the same as you and me": encounters with the gadia in the East Kimberley', Aboriginal History, 3(2), 1979:96-108. Banggaiyerri: the story of Jack Sullivan, as told to Bruce Shaw. Canberra, 1983.

Stanner, W.E.H. 'Durmugan, a Nangiomeri', in Casagrande, Joseph B. ed. In the company of man. New York, 1960:63-100.

Tedlock, Dennis. The spoken word and the work of interpretation. Philadelphia, 1983.

Thomas, Athol. Bulls and boabs: Kimberley people and places. Perth, 1984. 